\title{
Erratum to: Marking live conifer pollen for long-distance dispersal experiments
}

\author{
Claire G. Williams • Patrick von Aderkas
}

Published online: 9 March 2011

(C) Springer-Verlag 2011

Erratum to: Oecologia (2011) 165:249-254

DOI 10.1007/s00442-010-1817-8

The article was inadvertently published twice in Oecologia (2011) 165:249-254 DOI 10.1007/s00442-010-1817-8 and Oecologia (2011) 165:255-260 DOI 10.1007/s00442-0101825-8. The correct article of record is DOI 10.1007/ s00442-010-1817-8.

The online version of the original article can be found under doi:10.1007/s00442-010-1817-8.

C. G. Williams ( $\square)$

National Evolutionary Synthesis Center (NESCent)

and Forest History Society, Durham, NC 27705-4667, USA

e-mail: claire-williams@fulbrightmail.org;

claire.williams@duke.edu

P. von Aderkas

Department of Biology, Centre for Forest Biology,

University of Victoria, Victoria, BC V8W 3N5, Canada

e-mail: pvonader@uvic.ca 